\title{
Theoretical Origin and Realistic Enlightenment of the Ecological Construction Thought of Chinese Communist Party
}

\author{
Linchan Sun \\ History and Geography College \\ Longdong University \\ Qingyang, China 745000
}

\begin{abstract}
Based on an overview of the international social development situation, accurately grasping the characteristics of the times, based on the experience of Marx and Engels' ecological thinking, the Chinese Communists analyze the dialectical relationship between humans, society, and nature. And combined with traditional Chinese ecological thought, the "harmony of man and nature" of Confucianism, "Tao models itself after nature" of Taoism, and "all beings have Buddha nature" of Buddhism, it also puts forward the main content of the Chinese Communist Party's ecological construction thought, the core of the Chinese Communist Party's ecological construction thought, legal system construction and scientific and technological progress as the source of power and the requirements of the Chinese Communist Party's hypothetical thinking.
\end{abstract}

Keywords-Chinese Communist Party; ecological construction; man and nature

\section{INTRODUCTION}

The Chinese Communist Party has gone through a long historical process of exploring ecological thought. From "greening the motherland and building a happy homeland" in the early days of the founding of the People's Republic of China, the "Eco-Construction" was first clearly stated in the report of the 17th National Congress of the CPC, to the emphasis on ecological construction in the report of the 18th National Congress of the CPC, and to today's central collective leadership to promote the overall deployment of ecological construction, China has always attached great importance to the protection and construction of the ecological environment. It can be seen that, while dealing with the relationship between man and nature, practice and theoretical achievements, the Chinese Communist Party is able to understand and grasp the party's advanced governing philosophy of adhering to and developing socialism with Chinese characteristics. According to the ecological construction theory of the Chinese Communist Party and the national ecological construction policy, ecological construction will become an important part of the road of building socialism with Chinese characteristics.

\section{ECOLOGICAL THOUghts DERIVED FROM MARX AND ENGELS}

The discussion of the relationship between man, society and nature by Marx and Engels profoundly revealed the essential connection between man, society and nature. Marx and Engels pointed out that there is a dialectical unity of man, society and nature in human practice. In terms of the dialectical relationship between man and nature, according to Marx and Engels, man and nature are an objective relationship. This means that man and nature are an organic whole, an integrally inseparable whole. Man and nature are interdependent objects, and each object has an object existence as its premise.

Marx believes that man is a natural being, man develops from nature, and human blood, body, and mind belong to nature. Marx said: "Man itself is a product of nature, developed in and with his environment."[1] At the same time, Marx pointed out that nature, as an inevitable object of man, is the composition of man. Man has turned nature into human needs in the actual activities. At the same time, Marx emphasized that although human material life and spiritual life are inseparable from nature, the biggest difference between man and other living things is that man has subjective initiative.

In terms of the dialectical relationship between man, society and nature, Marx and Engels believe that because people have a dynamic and creative lifestyle, they have changed the natural existence of people as "an appurtenance to a certain narrow group of people".[2] This gives people sociality and becomes a social being. "Humanized nature" is human society in its substance. Marx pointed out in "Economic and Philosophical Manuscripts 1844": "Society is the complete unity of man and nature", "Society is the completed naturalism of man and nature, the realized humanism of man and nature."[3]It can be seen that in the eyes of Marx, the unity of man and nature can be achieved in society, and it can only be achieved in society. The proposition that society is the integral essence of man and nature sums up the long-term opposition between nature and society and truly dispels the thought of trying with one party to dissolve and forbid the other. Nature and society have 
never been strictly opposed. Anyone lives in the natural and social world of mankind. As Engels put it, "We live not only in nature, but in human society."

The Communist Manifesto stated that "the productive forces created by the bourgeoisie in its less than one hundred years of class rule are greater than the total productive forces created by all generations in the past", which are specifically manifested in "the conquest of natural forces, the use of machinery, the application of chemistry in industry and agriculture, the movement of ships, the passage of railways, the use of telegraphs, the reclamation of the entire continent, and the navigation of rivers. This seems to be a large population called out by underground spells. "[5] Not only that," From the point of view of the bourgeoisie, there is nothing in the world that does not exist for money, not even themselves. Because they live to make money, they don't know they have other happiness except to get rich quickly. Apart from the loss of money, they do not know that there is any other pain.[6] Marx pointed out sharply: "Although capitalist production is very rampant, it is very wasteful on personal materials. As on the other hand, because its products are distributed through commerce and its competition, it is also a waste of material information. On the one hand, the capitalist mode of production gathers the historical driving force of society, and on the other hand, it destroys the material exchange between man and land.

Marx analyzed that as long as the capitalist mode of production exists, it is impossible to eliminate the contradiction between man and man and man and nature. And this is exactly the crux of capitalism: "The crux of capitalist society lies in its social regulation that has no consciousness from the beginning to the end of production. What is reasonable and what is naturally necessary are only realized as an average functioning blindly "[8] In the Critique of the Gotha Programme, Marx further stated that the root of the ecological crisis is the capitalist system.

\section{THE IDEA OF "HARMONY OF MAN AND NATURE” ORIGINATED FROM CONFUCIANISM}

Confucianism holds that "Paradise", as the idea of feudal society, has the ability to dominate everything and is the supreme ruler. Confucius believed that people should respect nature, awe nature, revere nature and obey nature, and emphasized that production activities should be carried out according to "God's will."

As the ideology of feudal society, Confucianism believes that "nature" is the will and the supreme ruler with the ability to dominate everything. Confucius believes that people should respect nature, awe nature, revere nature and obey nature, and emphasize that they should carry out production activities in accordance with the "destiny". In Mencius, Dedicated to Heart, it is stated that "everyone who knows his heart knows his nature. If he knows his nature, he knows nature." [9] The "heaven-human induction" doctrine of "correspondence between man and heaven" proposed by Dong Zhongshu summarizes the Confucian idea of the harmony of man and nature. During the Song and Ming dynasties, the Confucianists paid more attention to the internal communication between "heaven and man". Zhu Xi believes that "the heaven is the man, and the man is the heaven", and "the heaven and the man are only one thing." Wang Yangming of the Ming Dynasty believed that "human mind is heavenly principle". "The Book of Changes" expresses the Confucian view of ecological nature as "San Cai Theory", which believes that the entire universe is composed of "heaven", "earth", and "man", and believes that only "having all three of these at the same time" can constitute a complete living thing ("formation of natural phenomena").Its essence is "subject-object unity" and "the harmony of man and nature", emphasizing that human beings must obey the laws of nature.

In short, the Confucian idea of the harmony between man and nature has brought useful enlightenment, that is, while developing the economy, developing nature, and using resources, it is necessary to pay attention to coordinating the relationship between man and nature, combining economic development with nature, and improving the scientificity and rationality of developing nature and using resources. When solving the problem of shortage of resources, the Party rationally used the ideas of using the best of the materials advocated by Confucianism.

\section{IV. “TAO MODELS ITSELF AFTER NATURE” FROM TAOISM}

Taoism is not ecology, but Taoism is a religion that fully respects life and nature, contains rich ecological ideas, and has a special ecological perspective. In Taoism, respect for life and nature is an explanation of ecology. The theory of origin holds that everything in the world is gathered and dispersed by reason, which is the philosophical basis of Taoist ecological wisdom. Contrary to the Confucian interpretation of "heaven", Taoism denies that "heaven" has the will and believes that "heaven" is the natural heaven.

Taoism believes that "Tao" is the source of the universe higher than "Heaven, earth". "Tao" is the fundamental basis for the creation of all things in the universe and the highest body for the creation, operation and development of all things. Man and nature are the incarnation of the Tao. According to Taoism, everything in heaven and earth is born of "Tao," so "all things have Taoism." Lao Tzu proposed "man follows the earth, earth follows the heaven, heaven follows the Tao, and Tao models itself after nature." [10] This tells people that if the things in this world want to survive and operate, they must follow the natural laws of the universe. "Huang Di Yin Fu Jing" states: "Essence of heaven and earth can be ingested by all things; all things can be used by human beings. If human beings overuse all things, they will be destroyed by all things. Only by properly grasping these three kinds of misappropriation relations can the "Three be harmonious." [11] In the Taoist view, man is the most aura and intelligent thing, which advocates that people should cherish other things to live in harmony with nature.

Taoism believes that man and nature are interdependent. In Taoist view, nature is the prerequisite for human beings to survive, and human beings must protect nature in order to obtain more lasting development. "Taiping Scriptures" states: 
"Human life is in heaven and earth, and those who want to be safe must first settle in it, and then get long safe." [12] That is, human life exists between heaven and earth. If man wants to survive and develop, he must first make heaven and earth harmonious, and then he can better survive and develop. The "Yin Fu Jing" also says: "Observe the way of heaven and perform the mission of heaven, and it's done." [13] It says that it is necessary to understand and follow the laws of nature in order to achieve harmony with nature. All in all, Taoism's concept of "Tao and the laws of nature" emphasizes the harmony of heaven and man. Human beings are closely related to the survival of everything in nature. It requires human beings to understand and master the laws of nature and to act in accordance with them. Taoism believes that the harmony between man and nature is not only a serious problem in today's human society, but also an eternal spirit and the idea of the harmonious coexistence of man and nature in the future.

"Tao models itself after nature" means that all things or phenomena are not created out of thin air or exist in isolation. They can only be established through various causes and conditions. Once the causes and conditions formed are dispersed, the matter itself will be put on hold. This is because Taoism largely respects the causal relationship between life and nature. The place where Taoist Temple is located are all green landscapes, comfortable environment and ecological harmony. The advanced nature of Chinese ancient ecological wisdom values and the scientific nature of some ideological content are important theoretical and practical references for people to think about ecological issues and to the important theoretical sources of the CPC's ecological theory.

\section{REALISTIC ENLIGHTENMENT OF ECOLOGICAL CONSTRUCTION THOUGHTS}

Ecology is an orderly ecological operation mechanism and a good ecological environment constructed from material, spiritual and institutional achievements. Protecting natural resources, respecting the laws of nature, and caring about the natural environment are the most direct and effective ways to improve the ecological environment, make rational use of nature, and develop ecological economy. The rational use of nature requires all economic activities including ecological benefits, economic structure, growth model, and circular economy, which meets the requirements of ecological balance.

Xi Jinping pointed out that in the process of ecological construction, the most fundamental problem is the improvement of the ecological legal system, and the most important problem is to provide external protection for the ecology. The Third Plenary Session of the Eighteenth Central Committee proposed the construction thought of the ecological environment and set the construction goal of "beautiful China". The realization of this goal also depends on the improvement of policies and regulations and the intensity of supervision and implementation.

From the perspective of overall planning, the scientific concept of development is the process of formulating the strategic depth of the policy system. In the current environment, it is recommended to look farther, clarify the rights and responsibilities of each department and unit, and delimit the environmental protection work in the field of ecological environment, make a unified and clear statement on the authority of the environmental protection department, clarify the subordinate relationship between various departments, and the relationship between different laws and regulations. This will enable laws, policies and government agencies to more effectively increase the efficiency of environmental protection and ecological work. The right to a good environment is an inherent right of human life. Therefore, citizens should be given the right to protect the environment and this should be written into the constitution.

The ecological ideology of the Chinese Communist Party requires more law enforcement and improved operability of laws and regulations. The biggest problem that has plagued the environmental protection department for many years is the lack of operable laws and regulations when dealing with practical problems. These problems are reflected in different punishment standards, which undermine the fairness of ecological law and also causes many law enforcement disputes. Therefore, the legal principles and the operability of policies should be strengthened. This shows that when amending the bill, restrictions on specific policy provisions should be relaxed so that local environmental departments can formulate policies based on local environmental and ecological characteristics. At the same time, the law should give it sufficient penalties to make environmental law enforcement more effective and deterrent. "If the ecological environment is not effectively protected, this will not only make sustainable economic and social development impossible, but also the people will not be able to drink clean water, breathe clean air, and eat safe food, which will inevitably lead to serious social problems."[14]

At the beginning of the founding of the People's Republic of China, "construction" has become a major problem for the entire party and the people of the whole country. In order to establish the country, the Chinese Communist Party in various fields have actively and effectively explored and practiced, and formed a series of achievements in the localization of Marxism, especially reform and development. Marxism believes that "man is a part of nature", "a living natural being" and "man itself is a product of nature, developed in and with his environment". Therefore, man must take the natural world as a prerequisite for survival and development, and at the same time act according to objective laws, otherwise "it will only bring disaster."[15]

\section{CONCLUSION}

Returning the human world and human relations to oneself, and ultimately achieving "the producers united by socialized people, will reasonably adjust the material exchange between them and nature, relying on the least amount of power, and carry out this material transformation under the conditions most deserving and most suitable for their human nature." The well-off society we are building is a comprehensive well-off society. Especially when China's current ecological environment is relatively fragile, how to 
[16] Ba Zhipeng: "The Origin of the Chinese Communist Party's Thoughts on Ecological Civilization Construction", "Gansu Social Sciences", No. 5, 2013. (in Chinese) society directly affects the success or failure of building a well-off society in an all-round way. Research on China's ecological ideological construction is an inevitable requirement for China to follow the path of ecological construction in the future. Only by scientifically understanding the Chinese Communist Party's innovative ideas on ecological construction can we better understand China's future development path and promote China's ecological construction more effectively.

The Chinese Communist Party's ecological thoughts reflect the new concept that people use to protect, respect and live in a harmonious and natural environment. This new perspective emphasizes that man is not the master of nature and must promote harmony between man and nature in order to achieve all-round human development. The Chinese Communist Party's ecological thinking can guide ecological practice and avoid circuitous twists and turns, which is conducive to achieving the goal of a beautiful China. Therefore, it is necessary to clarify the background of the Chinese Communist Party's ecological thoughts, further explore the scientific connotation and realization methods of the Chinese Communist Party's ecological thoughts, and provide better theoretical support and practical guidance for the development of the socialist ecology and the construction of "Beautiful China".

\section{REFERENCES}

[1] Complete Works of Marx and Engels (Vol. 3), Beijing: People's Publishing House, 1995, pp. 374-375. (in Chinese)

[2] Complete Works of Marx and Engels (Vol. 3), Beijing: People's Publishing House, 1995, p. 19. (in Chinese)

[3] Complete Works of Marx and Engels (Vol. 3), Beijing: People's Publishing House, 1995, p. 121-122. (in Chinese)

[4] Complete Works of Marx and Engels (Vol. 3), Beijing: People's Publishing House, 1995, p. 230. (in Chinese)

[5] Complete Works of Marx and Engels (Vol. 3), Beijing: People's Publishing House, 1995, p. 277. (in Chinese)

[6] Complete Works of Marx and Engels (Vol. 2), Beijing: People's Publishing House, 1995, p. 564. (in Chinese)

[7] Complete Works of Marx and Engels (Vol. 3), Beijing: People's Publishing House, 1995, p. 525. (in Chinese)

[8] Complete Works of Marx and Engels (Vol. 3), Beijing: People's Publishing House, 1995, p. 525. (in Chinese)

[9] Liu Juntian, et al. Full Translation of The Four Books, Guiyang: Guizhou People's Publishing House, 1988, p. 605. (in Chinese)

[10] Rao Shangkuan Noted: Lao Tzu, Beijing: Zhonghua Book Company, 2006, p. 63. (in Chinese)

[11] Ren Farong, "Huang Di Yin Fu Jing · Interpretation of Huang Shi Gong Su Shu": Oriental Press, 2009, p. 68. (in Chinese)

[12] Translated and Noted by Yang Jilin, Taiping Scriptures, Beijing: Zhonghua Book Company, 2013, p. 79. (in Chinese)

[13] Translated and Noted by Yang Jilin, Taiping Scriptures, Beijing: Zhonghua Book Company, 2013, p. 88. (in Chinese)

[14] Liu Xiaodan: "Analysis of the Ecological Civilization Construction Thought of the Communist Party of China", "Statistics and Management", No. 11 of 2017. (in Chinese)

[15] Chen Jun: "Exploration of Ecological Civilization Thought of the Communist Party of China", "The Journal of Yunnan Provincial Committee School of the CPC", No. 2, 2016. (in Chinese) 